he also wrote the first report of the College of Aeroneutics to be issued.

Duncan's teaching at the College was outstanding in excellence, as is witnessed by the fact that many of his students who specialized in aerodynamics now occupy major positions in the aircraft industry and in aeronautical research. He left Cranfield in 1950 to become the firgt Mechan professor of aeronautics and fluid mechanics in the University of Glasgow, a post which he held until the end of his life. He had been chairman of the Aeronautical Research Council since 1957, and was very active not only on the Council but also on many of its committees and sub-committees.

Prof. Duncan was an able mathematician and a first-class engineer, painstaking and thorough in all his work, and a great inspiration to those who had the good fortune to work with him. He was elected a Fellow of the Royal Society in 1947 and was appointed C.B.E. in 1953. His publications, besides the two books already mentioned, include one on "Physical Similarity and Dimensional Analysis", together with numerous reports and papers published in the Reports and Memoranda of the Aeronautical Research Council, the Proceedings of the Royal Society, and the Philosophical Magazine. His death will be felt as a great loss by his many friends and collaborators, and by the world of mechanical engineering in general.

ERNEST F. ReLF

\section{Prof. J. G. Andersson}

Prof. Johan GunNar Andersson, formerly director of the East-Asiatic Collections at Stockholm, was one of the Swedes who have made lasting contributions to our knowledge about the natural resources of Chine and the history of the civilization of that country.

$\mathrm{He}_{\theta}$ was born on July 3,1874, at Knista in the province of Örebro, and died in Stockholm on October 29. After studying at the University of Uppsala, he obtained there the degree of M.Sc. in 1901 , became D.Sc. in 1902, and was appointed professor of geography in 1906. Already during his years as a student he devoted himself to the examination of the Silurian deposits of his native county of Närke and of öland. These investigations resulted in a couple of palæontological communications and a study of the distribution of phosphorites in the Silurian.

As a young student he took part in several expeditions into the Arctic regions. Thus he was a member of the expedition to Spitsbergen led in 1898 by the Swedish polar explorer A. G. Nathorst. In 1899 Andersson undertook an expedition of his own to Beeren Island. The geological results of this undertaking he described in his doctoral thesis, "Über die Stratigraphie und Tektonik der Bären Insel". When in the years 1901-3 Otto Nordenskjöld undertook his famous Antarctic expedition, Andersson was second in command, and when Nordenskjöld together with some other members had established winter quarters on Snow Hill, Andersson took over the lesdership of the expedition to South Georgia, the Falkland Islands, and Tierra del Fuego, and also during the second trip of the vessel to the Antaretic. Afterwards Andersson left the vessel with two companions in order to reach Nordenskjöld's winter quarters by land. Before reaching it he was, however, forced to spend a winter under very trying conditions. He then joined Nordenskjöld's group in the following spring. In the meantime, their ship foundered in the pack-ice, yet without loss of human lives. This expedition and its rescue by an expedition sent out from Argentina forms one of the more thrilling chapters in the history of the exploration of the polar regions.

In 1906 Andersson was made head of the Geological Survey of Sweden. After having had leave of absence since 1914, he left this post in 1916. During his comparatively short time as head of this organization, he introduced a number of new and important investigations into its programme. This applies first of all to the production of oil and radium from the oil-shales. The organization of the Geological Survey as established in 1914, which has remained in force to the present day, is to a large extent due to him. During the Eleventh International Geological Congress, held at Stockholm in 1910, he was, partly in collaboration with $H$. Munthe and A. Gavelin, the editor of the publications of the Congress.

As mentioned already, Andersson had obtained leave of absence in 1914 from his post as head of the Geological Survey, and had entered the service of the Chinese Government as mining adviser and organizer of the geological exploration of the ore and mineral resources of China. It was during this period that he became widely known as an explorer of China. In addition to the study of ore geology, he found time for extensive studies of the fossil faunas and floras of China as well as for remarkable archæological excavations that threw light on the earliest settlement of China. In his endeavours he enjoyed powerful support from the Chinese Government and from the Swedish Parliament. From this field of activity 'China Gunnar', as he was called in many circles, brought back extensive collections which are now in different Swedish museums.

After his return from China, Andersson was appointed in 1926 to a chair of geology in the University of Stockholm. From this he retired, however, in the following year, in order to devote himself to the arrangement of his collections, and to a new trip to China. On his return from his second visit to Chine he was made director of the East-Asiatic Collections in Stockholm, and was given a personal chair in EastAsiatic archæology which he then occupied until 1939.

Andersson published the results of his researches and explorations in a great number of scientific papers. His studies in the Far East were summarized in his "Topografisk-arkeologiska studier i Fjärran Östern" (1939). He had a great gift of popularizing his knowledge, both as a lecturer and as an author. In 1926 he published his account of China, "Draken och de främmande djävlarna", followed by "Don gula jordens barn" (1932), the autobiographical "Kineser och pingviner" (1933), and "Under brinnande krig" (1938). He surveyed his own life and his life's philosophy in a book, "Mitt liv och min tro" (1956).

ERIK ÅHMAN

\section{Dr. Louis Clarke}

Louis Clarke's death on December 13 leaves a gap in the hearts of his innumerable friends, for he was a much-loved man. He was wealthy and was blessed with intelligence and common sense, with a lively understanding of human nature and with the standards of behaviour of his Christian Victorian upbringing. He travelled widely after leaving Cambridge, especially in South America and 
Abyssinia, and was extremely knowledgeable in matters of archæology and art. Hence his two official jobs, first as curator of the Museum of Archæology and Ethnology at Cambridge, and later as director of the Fitzwilliam Museum.

But the outstanding fact was that Louis could neither be described as an academic nor as an ordinary person. He took a very modest degree, and, though in later life h:s eminence was such that his University gave him an honorary doctorate, he was essentially an example of the fine fruit of what England so specially has produced in the past : he was a distinguished amateur. This is high praise, and it was only possible because in his early life his intellectual energies had not been canalized into a narrow channel : he had had opportunity and leisure to cultivate wide interests and friendships and to gain a broad, wise outlook on life. His knowledge became encyclopædic : he could give you the provenance of any object you might offer for his inspection! Those who knew him well will never forget his enormous, cheery voice resounding through the two Museums he successively controlled, nor his capacity, possibly unrecognized by himself, to unite any team with which he worked into a whole.
At the Museum of Archæology and Ethnology, where he followed Baron von Hügel and Dr. A. C. Haddon and where much had been done to build up a new Museum, it was nevertheless under his direction that it became what it is to-day. He was extremely generous, too, in his gifts to the collections, and much more generous than people knew throughout his life to young or struggling archæologists, finencing 'digs' in out-of-the-way parts of the world and adding the results of their excavations to the Museum collections. At the Fitzwilliam his influence was at first to some extent crippled by the War and all that world upheaval meant to a great art museum, but afterwards he was able to do much to further the objects of that universally known institution.

But facts give no picture of the man, with his kindly humour and tremendous knowledge of people, a knowledge which began in his own family of thirteen brothers and sisters and extended to include savants from all over the world. Above all, there was nothing ungenerous in his whole make up, and he has been an ornament to the Cambridge of his generation. For some years his heart had given him trouble, and he died quietly in Cambridge in his eightieth year on December 13.

M. C. BuRKITT

\section{NEWS and VIEWS}

\section{Geological Society of London :}

Awards

THE Council of the Geological Society of London has made the following awards for 1961: Wollaston $M e d a l$, to Prof. Roman Kozlowski, emeritus professor of palæontology, University of Warsaw, in recognition of his distinguished contributions to palæozoology, especially to knowledge of the graptolites; Murchison Medal, to Mr. W. N. Edwards, assistant director, Geological Survey of Great Britain (Leeds), for his contributions to the stratigraphy and structure of the Coal Measures, particularly in the YorkshireNottinghamshire Coalfield ; Lyell Medal, to Dr. J. V. Harrison, lately reader in structural geology, University of Oxford, for his contributions to structural geology and his pioneer work in remote countries ; Bigsby Medal, to Prof. Alwyn Williams, professor of geology, Queen's University, Belfast, in recognition of his work on the Lower Palæozoic stratigraphy, palæontology and structural geology; Wollaston Fund, to Dr. E. A. Vincent, reader in mineralogy, University of Oxford, for his work on the irontitanium minerals and on geochemistry; Murchison Fund, to Dr. J. Ineson, district geologist (Water Department), Geological Survey and Museum, London, for his fundamental contributions to the investigation of ground-water resources in Britain; a moiety of the Lyell Fund to Dr. R. G. West, demonstrator, Department of Botany, University of Cambridge, for his contributions to the geology and palrobotany of the Pleistocene of the British Isles; another moiety of the Lyell Fund to Dr. W. T. Dean, Department of Palæontology, British Museum (Natural History), London, for his work on the stratigraphy and palæontology of the Middle and Upper Ordovician in Great Britain.

\section{Royal Society and Nuffield Foundation Common- wealth Bursaries}

AwARDS under the Royal Society and Nuffield Foundation Commonwealth Bursaries Scheme have been made as follows: Mr. J. Attridge, lecturer in zoology, Birkbeck College, to assist him in doing further work on the Dinosaur beds, and other fossil reptile deposits, of the Karroo System in Southerm Rhodesia, from June to October 1961 ; Dr. M. M. Chakrabarty, reader in applied chemistry, University of Calcutte, to assist him in studying new techniques for the investigation of fatty oils at the Prairie Regional Laboratory, Saskatoon (and possibly also at the Paint Research Station, Teddington), for about six months from March 1961 ; Prof. J. H. O. Day, professor of zoology, University of Cape Town, to enable him, for about nine months from February 1961, to study type specimens at the British Museum (Natural History) in connexion with the preparation of a monograph on the South African Polychaeta; Dr. W. H. Elliott, Biochemistry Department, John Curtin School of Medical Research, Australian National University, Canberra, to assist him in visiting Cambridge for about a year from September 1961 in order to study microbiological techniques; Dr. D. E. Hoare, lecturer in physical chemistry, Queen's College (Dundee), University of St. Andrews, to enable him to study reactions of hydroxyl radicals with hydrocarbons at the National Research Council, Ottawa, from April to September 1961; Mr. C. R. Horrell, of the Department of Agriculture, Uganda, to enable him to visit Queensland from January to April 1961 to study the development of tropical pasture grasses and legumes for the production of temporary leys ; Dr. C. A. Hurst, senior lecturer in mathematical physics, University of Adelaide, to assist him in visiting Edinburgh for about eight months from February 1961 in order to investigate the properties of relativistic two-body equations; Prof. J. C. Jaeger, professor of geophysics, Australian National University, Canberra, to enable him to carry out a study of stresses in deep mines and correlation with seismic observations, at the Bernard Price Institute, Johannesburg, for about three months 